\title{
Effect of aging and interaction of cooling fluid with heat exchangers material in long-lasting durability test
}

Efforts to improve engine cooling efficiency by usage of heat exchanger as well as research on cooling fluids composition and properties are well described. Studies on heat exchangers are focused mainly on their durability properties, while cooling fluids' development is lately concentrating on nanofluids. In this paper physicochemical properties changes of diluted glycol-based cooling fluid in a long-term durability test of vehicle heat exchanger, were investigated. Following parameters were measured: density of coolant, $p H$ value, elements content in coolant, and reserve alkalinity. Above mentioned analyses were performed on samples collected both in the beginning and periodically after every 500 hours of durability test which lasted for 3000 hours in total. The performed study leads to conclusion that interaction of cooling fluid with material of heat exchanger and changes in glycol composition during long-lasting durability test allows to determine aging effect of applied glycol solution on heat exchanger wear.

Key words: glycol chemical-physical properties, cooling fluid, heat exchanger, corrosion resistance

\section{Introduction}

Heat transfer and efficient cooling of vehicle engine is one of the key processes in proper engine work. Heat produced during engine work and fuel combustion needs to be dissipated, and for that reason a heat exchanger is placed in each vehicle.

The role of heat exchanger, which in automotive the most often is a radiator, is to exchange efficiently heat between two or more fluids. This process leads to heat dissipation, and then to engine cooling [1-3]. Typically radiators are forced air-cooled with crossflow [4], with large enough area for heat transfer.

Vehicle radiators, due to their exposure to high temperatures and temperature changes, have to meet a number of requirements, among them i.e. tightness, thermal efficiency, mechanical durability, corrosion resistance etc. In fact, resistance to thermal shocks is the basic durability parameter of radiators $[5,6]$. On the other hand, temperature changes and temperature gradient are the main factors influencing radiator corrosion resistance [3]. For that reason designing of efficient and durable radiator is a complicated matter [1]. The materials used for radiators are typically aluminum alloys, most often aluminum-manganese alloys (Al-Mn) due to their high tensile strength and good corrosion resistance, especially intergranular corrosion resistance [7].

Nowadays, a lot of effort is put into thermal efficiency improvement and fastening of the heat transfer [8-10]. From one point of view this can be achieved by maximizing heat transfer area as heat transfer efficiency is a function of heat exchange relative surface area and fluid temperature $[1,2]$. This can be done by using fins or microchannels [9], where the coolant flow is divided into a number of separated tube flows [4]. On the other hand, maximizing heat transfer area by i.e. increasing fins quantity, leads to undesirable increase of vehicle weight influencing fuel combustion efficiency [2]. This fact is in the opposite to another trend in automotive industry: downsizing.

In fact, heat transfer improvement by radiator's construction changes is now limited because of the physical limitations. For that reason the researches are focused now on cooling fluids development. Coolants used in vehicle should have high efficiency of heat dissipation and high thermal conductivity coefficient $[2,10-12]$, as their role is to act as a heat-exchange medium $[8,13]$.

Nowadays, the most widely used cooling fluids are water or ethylene glycol-based fluids [12], although their efficiency is relatively low. For this reason the possibility of employing nano-fluids, containing nanoparticles, is now under investigation. The main feature of nano-fluids is their high capacity of thermal properties enhancement [8]. It was observed, that application of nano-fluids can improve heat transfer by $25 \%$ [9] to even $50 \%$ [8]. Nano-fluids are fluids enriched by nanoparticles, which may be for example $\mathrm{ZnO}$, $\mathrm{CuO}, \mathrm{Al}_{2} \mathrm{O}_{3}, \mathrm{SiO}_{2}$ [2], $\mathrm{Cu}$ or $\mathrm{TiO}_{2}$ [2, 9]. Despite properties of nano-fluids, their usage is limited and OEMs still recommend glycol-based coolants for their automobiles [14].

Many tests for new models of radiators are usually required before their implementation, and are routinely performed, i.e. durability by thermal shocks, vacuum/helium tightness or external corrosion resistance for aggressive salt spray. The results of degradation study of radiator material, durability tests or radiators operational parameters are described in literature. However, data regarding radiator's internal material performance or cooling fluid long-term performance is not easily available

The aim of present work was to monitor changes in chemical and physical properties of selected cooling fluid during long term durability test of three radiators. The radiators were exposed to high temperature of cooling fluid for more than $3000 \mathrm{~h}$, and samples of coolant were collected every $500 \mathrm{~h}$.

This paper discusses elements concentration changes in Glysantin G48, glycol based fluid, which are a reflection of radiator's material wear and cooling fluid condition. Moreover, some physical parameters were also observed: changes in reserve alkalinity, $\mathrm{pH}$ value and density, which may also reflect the aging effect of cooling fluid and material. 


\section{Experimental}

\subsection{Testing stand}

Durability test of three selected heat exchangers (Tested parts \#1...\#3) were performed in BOSMAL Automotive Research and Development Institute Ltd. The scheme of testing stand is presented in Fig. 1.

The test was performed in three steps and lasted 3003 hours in total. The temperature during the 3000 hours of the test was constant $\left(120^{\circ} \mathrm{C}\right)$, and it was increased to $137^{\circ} \mathrm{C}$ during the last three hours of the test. Cooling fluid was heated with the use of pipe exchanger before introduction to radiators in order to simulate engine work.

The pressure of the fluid was measured in front of the radiators, and was in the range of $(1.5 \ldots 2.3) \times 10^{5} \mathrm{~Pa}$. The summary of test parameters is presented in Table 1 .

Table 1. Durability test parameters

\begin{tabular}{|c|c|c|c|}
\hline Test step & Time & Temperature & Pressure \\
\hline- & {$[\mathrm{h}]$} & {$\left[{ }^{\circ} \mathrm{C}\right]$} & {$\left[\times 10^{5} \mathrm{~Pa}\right]$} \\
\hline 1 & 2500 & $120 \pm 0.5$ & $1.5 \pm 0.05$ \\
\hline 2 & 500 & $120 \pm 0.5$ & $2.1 \pm 0.05$ \\
\hline 3 & 3 & $137 \pm 2.0$ & $2.3 \pm 0.05$ \\
\hline
\end{tabular}

The flowrate of cooling fluid in each heat exchanger was also monitored and recorded, and was $4200 \mathrm{~L} \mathrm{~h}^{-1}$. At the start of the test and every 500 hours of test duration a 50 $\mathrm{mL}$ sample of cooling fluid was collected, and physicalchemical analysis were performed.

\subsection{Cooling fluid}

Cooling fluid which was used in durability test was Glysantin $G 48^{\circledR}$. The basis of Glysantin G48 is ethylene glycol, and according to Data Sheet [15] Glysantin G48 contains a corrosion inhibitor package based on organic acids salts and silicates. The main objective of Glysantin G48 is to protect engines against corrosion, overheating and frost damage. Moreover, Glysantin G48 does not contains nitrites, amines and phosphates.

Before use, concentrated Glysantin G48 was diluted with distilled water to concentration recommended by producer [15].

\subsection{Physical-chemical analysis}

Some physical properties of Glysantin G48 are mentioned in Data Sheet, i.e. density, viscosity, boiling point, flash point, $\mathrm{pH}$ value, reserve alkalinity or ash content. Typical values for concentrated Glysantin G48, given by producer, are presented in Table 2 [15]. Besides physical data, no chemical properties or elements content are mentioned in Data Sheet. The only limitations in elements content refer to the water used to dilution of concentrated Glysantin.

Table 2. Physical properties of Glysantin G48 [15]

\begin{tabular}{|l|c|c|}
\hline Parameter & Unit & Value \\
\hline Density at $20^{\circ} \mathrm{C}$ & $\mathrm{g} \mathrm{cm}^{-3}$ & $1.121 \ldots 1.123$ \\
\hline Viscosity at $20^{\circ} \mathrm{C}$ & $\mathrm{mm}^{2} \mathrm{~s}$ & $24 \ldots 28$ \\
\hline Refractive index at $20^{\circ} \mathrm{C}$ & - & $1.432 \ldots 1.434$ \\
\hline Boiling point & ${ }^{\circ} \mathrm{C}$ & $>165$ \\
\hline Flash point & ${ }^{\circ} \mathrm{C}$ & $>120$ \\
\hline $\mathrm{pH}$ value & - & $7.1 \ldots 7.3$ \\
\hline Reserve alkalinity & $\mathrm{mL}$ & $13 \ldots 15$ \\
\hline Ash content & $\%$ & $<1.5$ \\
\hline Water content & $\%$ & $<3.5$ \\
\hline
\end{tabular}

Only few of listed in Table 2 parameters may change during coolant usage as a result of cooling fluid wear, while remaining are typical parameters independent of the wear.

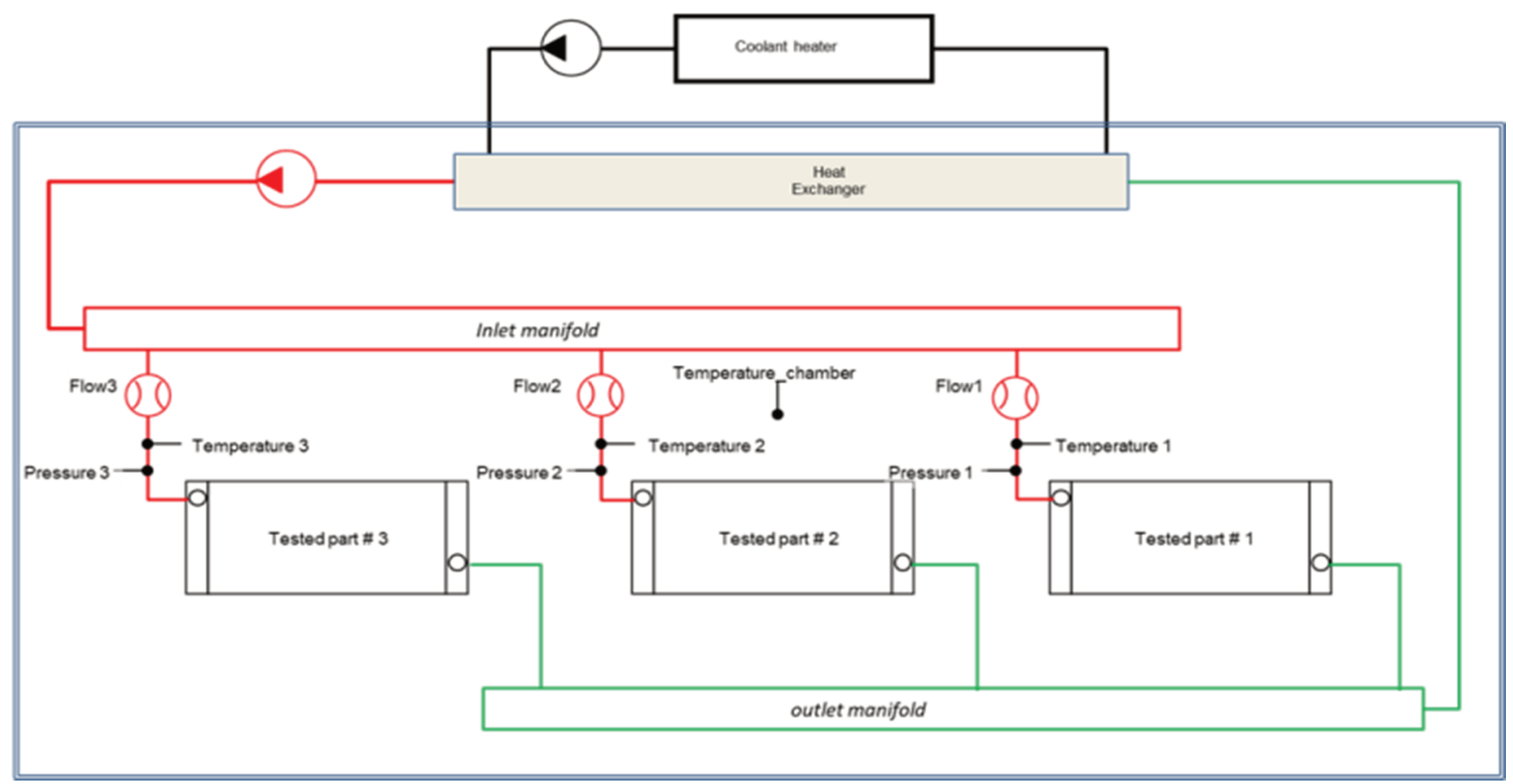

Fig. 1. The scheme of testing stand 
Following physical parameters were selected for monitoring the condition of tested fluid during durability test: density at $20^{\circ} \mathrm{C}, \mathrm{pH}$ value and reserve alkalinity, as this parameters may be the indicators of cooling fluid wear.

Polish Standards were applied for above mentioned analysis:

- reserve alkalinity (R.A.) by titration method was measured according to PN-C-40008-05:1993 [16],

- $\mathrm{pH}$ value by potentiometric was measured according to PN-C-40008-04:1992 [17],

- density was measured at $20^{\circ} \mathrm{C}$ by oscillometric method according to PN-EN ISO 12185:2002 [18].

Additionally, twenty different elements (including metals and non-metals) were also measured in each collected coolant sample. Elements concentration was measured by inductively coupled plasma optical emission spectrometer (ICP-OES) Perkin Elmer Optima 8300, with horizontal plasma and binary, radial and axial, observation system. Fluid samples collected every 500 hours and so called 'zero sample' (before the introduction to stand and start of the test) were diluted ten times with deionized water before analysis and then measured directly by means of ICP-OES method.

The elements measured were as follows: $\mathrm{Al}, \mathrm{B}, \mathrm{Ba}, \mathrm{Ca}$, $\mathrm{Cr}, \mathrm{Cu}, \mathrm{Fe}, \mathrm{K}, \mathrm{Mg}, \mathrm{Mn}, \mathrm{Mo}, \mathrm{Na}, \mathrm{Ni}, \mathrm{P}, \mathrm{Pb}, \mathrm{Si}, \mathrm{Sn}, \mathrm{Ti}$, and $\mathrm{Zn}$. Some of mentioned elements are typically present in Glysantin G48, as a result of organic acids salts package, and the remaining are indicators of heat exchangers' material wear. The changes in elements concentrations during durability test were monitored.

\section{Results and discussion}

During the durability test, at the start of the test and every $500 \mathrm{~h}$ of test, cooling fluid samples were collected. Some changes in physical properties of coolants were observed during the test in comparison to 'zero sample'.

As presented in Table 3 and in Fig. 2 slightly, but steady decrease in reserve alkalinity and $\mathrm{pH}$ value was observed along with test duration. No significant changes in density were observed, which may suggests that no significant changes in chemical composition (i.e. dissolved wear elements increase) occurred.

The changes in R.A. values may be a proof that the capacity of coolant to neutralize acidic glycol oxidation products is decreased, and therefore the protection ability of cooling fluid is decreased. This may effect in radiator's material corrosion, however the lowest value of reserve alkalinity during the test was still within recommended range $(10 \ldots 14)$. On the other hand, observed $\mathrm{pH}$ value decreased below 7.0 during the test, which value is out of range of safe coolant performance and will result in lower corrosion protection ability of the coolant. It can be stated, that safe working time of diluted Glysantin G48 in presented test conditions, is 1000 hours in maximum, which is not a long time, but it should be still keep in mind that cooling fluid worked simultaneously with 3 radiators, not with one as it usually takes place.

Along with physical properties, concentrations of wide range of elements were also measured. The results obtained can be divided into three groups (Tables 4-6). First group (Table 4) includes elements that are neither from additives package nor wear elements, and their concentration is below method detection limit (MDL). Among this elements are barium $(\mathrm{Ba})$, chromium $(\mathrm{Cr})$, iron $(\mathrm{Fe})$, lead $(\mathrm{Pb})$, tin $(\mathrm{Sn})$, and titanium (Ti). This elements are wear elements (i.e. Fe may derive from cylinder block, $\mathrm{Pb}$ may derive from heater core [20]). Because the present test was a stand test of radiators durability with simulation of high temperature from engine work, and not with a real engine, above mentioned elements were not detected in collected cooling fluid samples.

Table 3. Physical properties changes

\begin{tabular}{|c|c|c|c|}
\hline $\begin{array}{c}\text { Coolant } \\
\text { sample }\end{array}$ & R.A. $[\mathrm{mL}]$ & $\mathrm{pH}$ value & $\begin{array}{c}\text { Density at } 20^{\circ} \mathrm{C} \\
{\left[\mathrm{g} \mathrm{cm}^{-3}\right]}\end{array}$ \\
\hline 'zero sample' & 13.4 & 7.5 & 1.083 \\
\hline after $500 \mathrm{~h}$ & 13.1 & 7.4 & 1.082 \\
\hline after $1000 \mathrm{~h}$ & 12.9 & 7.1 & 1.092 \\
\hline after $1500 \mathrm{~h}$ & 12.6 & 6.5 & 1.095 \\
\hline after $2000 \mathrm{~h}$ & 11.8 & 6.4 & 1.087 \\
\hline after $2500 \mathrm{~h}$ & 11.4 & 6.2 & 1.092 \\
\hline after $3000 \mathrm{~h}$ & 10.4 & 6.0 & 1.089 \\
\hline
\end{tabular}

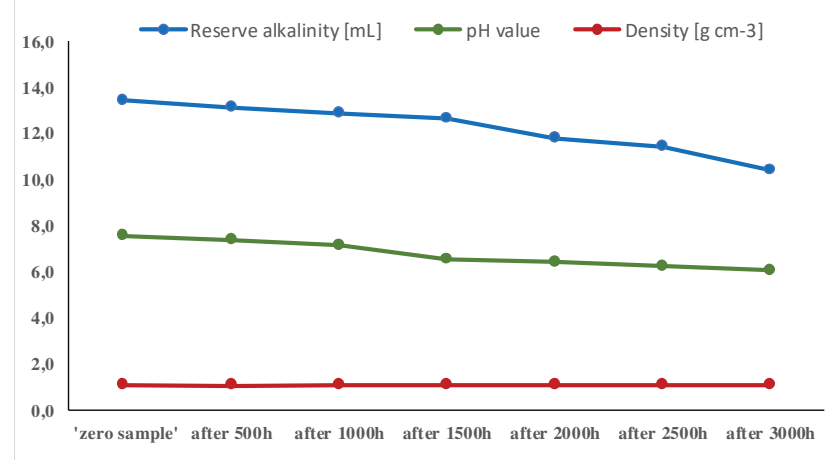

Fig. 2. Physical properties changes

Table 4. Elements not detected in coolant samples [mg/L]

\begin{tabular}{|c|c|c|c|c|c|c|}
\hline $\begin{array}{c}\text { Coolant } \\
\text { sample }\end{array}$ & $\mathrm{Ba}$ & $\mathrm{Cr}$ & $\mathrm{Fe}$ & $\mathrm{Pb}$ & $\mathrm{Sn}$ & $\mathrm{Ti}$ \\
\hline 'zero sample' & $<0.1$ & $<0.3$ & $<0.1$ & $<0.1$ & $<0.5$ & $<0.1$ \\
\hline after $500 \mathrm{~h}$ & $<0.1$ & $<0.3$ & $<0.1$ & $<0.1$ & $<0.5$ & $<0.1$ \\
\hline after $1000 \mathrm{~h}$ & $<0.1$ & $<0.3$ & $<0.1$ & $<0.1$ & $<0.5$ & $<0.1$ \\
\hline after $1500 \mathrm{~h}$ & $<0.1$ & $<0.3$ & $<0.1$ & $<0.1$ & $<0.5$ & $<0.1$ \\
\hline after $2000 \mathrm{~h}$ & $<0.1$ & $<0.3$ & $<0.1$ & $<0.1$ & $<0.5$ & $<0.1$ \\
\hline after $2500 \mathrm{~h}$ & $<0.1$ & $<0.3$ & $<0.1$ & $<0.1$ & $<0.5$ & $<0.1$ \\
\hline after $3000 \mathrm{~h}$ & $<0.1$ & $<0.3$ & $<0.1$ & $<0.1$ & $<0.5$ & $<0.1$ \\
\hline
\end{tabular}

The second group of elements includes elements coming from additives package. Among this elements sodium $(\mathrm{Na})$, boron $(\mathrm{B})$, potassium $(\mathrm{K})$, phosphorus $(\mathrm{P})$, molybdenum (Mo), and silicon ( $\mathrm{Si}$ ) have to be mentioned. Boron is usually added to cooling fluid in form of borates, especially sodium borate, and silicon in form of silicates. Potassium may be in form of salt, but the addition of $\mathrm{K}$ in tested coolant is not very high. Similarly, addition of Mo and P is not very high in cooling fluid under study. The role of all these additives is to inhibit material corrosion by buffering properties and to act as anti-foam agents $[19,20]$. 
The concentrations levels of elements from additive package during the durability test are presented in Table 5. The changes in concentrations levels of $\mathrm{Na}$ and $\mathrm{B}$ during the test are graphically presented in Fig. 3, of $\mathrm{Si}$ and $\mathrm{P}$ in Fig. 4, while concentration changes of Mo and $\mathrm{K}$ are presented in Fig. 5. The elements were grouped on the basis of the trends in concentration changes.

Table 5. Changes in additive elements concentrations [mg/L]

\begin{tabular}{|c|c|c|c|c|c|c|}
\hline $\begin{array}{c}\text { Coolant } \\
\text { sample }\end{array}$ & $\mathrm{B}$ & $\mathrm{Na}$ & $\mathrm{K}$ & $\mathrm{Si}$ & $\mathrm{P}$ & $\mathrm{Mo}$ \\
\hline 'zero sample' & 988 & 4407 & 19.4 & 116 & 9.4 & 1.4 \\
\hline after $500 \mathrm{~h}$ & 950 & 4267 & 27.2 & 89.4 & 21.0 & 1.3 \\
\hline after $1000 \mathrm{~h}$ & 1078 & 4692 & 61.5 & 86.1 & 28.1 & 2.5 \\
\hline after $1500 \mathrm{~h}$ & 1200 & 5638 & 78.0 & 92.4 & 22.5 & 2.8 \\
\hline after $2000 \mathrm{~h}$ & 1218 & 5596 & 79.0 & 86.5 & 16.5 & 2.8 \\
\hline after $2500 \mathrm{~h}$ & 1236 & 5560 & 95.7 & 87.3 & 18.0 & 5.0 \\
\hline after $3000 \mathrm{~h}$ & 1190 & 5066 & 123 & 76.4 & 14.5 & 5.4 \\
\hline
\end{tabular}

It can be seen in Fig. 3 that changes in concentration values are very similar for boron and sodium. After initial slightly decrease in $\mathrm{B}$ and $\mathrm{Na}$ concentration, increase and then again decrease was observed. Although observed concentration changes of these elements occurred it cannot be stated that they are significant.

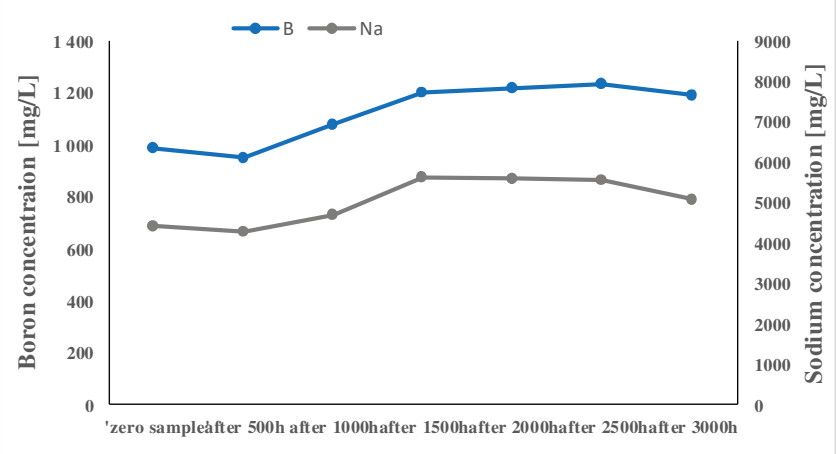

Fig. 3. Changes in $\mathrm{B}$ and $\mathrm{Na}$ concentration

No significant changes in concentration were observed for phosphorus and silicon, and the changes were very similar (Fig. 4). However, concentration of P and Si slightly decreased during the test, this decrease may testify Si or P additive wear and worsening of cooling fluid properties.

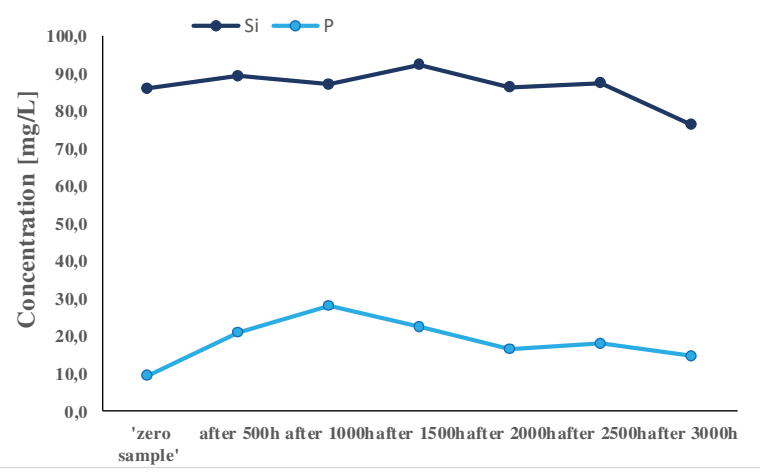

Fig. 4. Changes in $\mathrm{P}$ and Si concentration
Significant increase of concentration was observed for potassium and molybdenum (Fig. 5). It is difficult to conclude why concentration of this elements increased. One of the possible reasons is that compounds containing Mo and $\mathrm{K}$ have a tendency to precipitate from the solution. Another reason may be slightly decrease of water content in cooling fluid (slightly density increase - Table 3). For that reason concentration level of $\mathrm{K}$ and Mo increased from sample to sample.

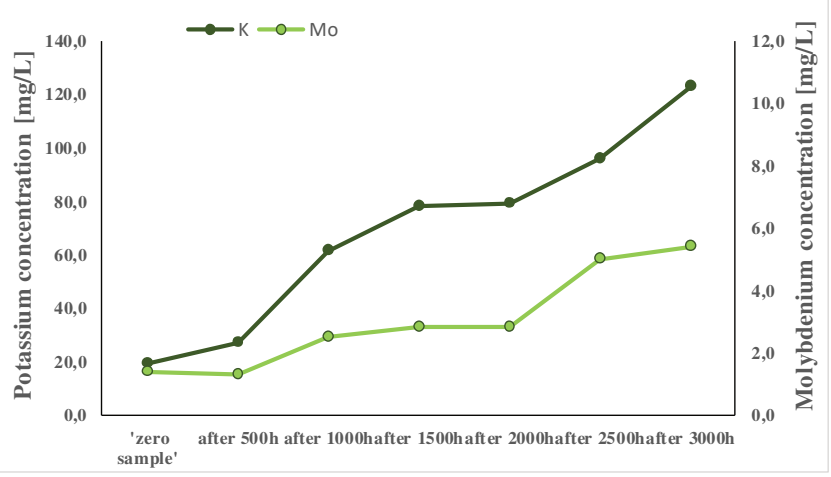

Fig. 5. Changes in $\mathrm{K}$ and Mo concentration

Wear metals present in collected fluid samples constitute third group of elements which should be discussed. Concentration changes of following elements were monitored: aluminum $(\mathrm{Al})$, iron $(\mathrm{Fe})$, copper $(\mathrm{Cu})$, zinc $(\mathrm{Zn})$, magnesium $(\mathrm{Mg})$, manganese $(\mathrm{Mn})$, and nickel $(\mathrm{Ni})$. The concentration levels of these elements in collected coolant sample are presented in Tables 6 and 7 and in Fig. 6 and 7 .

Table 6. Changes in wear elements concentrations $[\mathrm{mg} / \mathrm{L}]$

\begin{tabular}{|c|c|c|c|}
\hline $\begin{array}{c}\text { Coolant } \\
\text { sample }\end{array}$ & $\mathrm{Mg}$ & $\mathrm{Mn}$ & $\mathrm{Ni}$ \\
\hline 'zero sample' & 0.47 & 0.22 & 0.77 \\
\hline after $500 \mathrm{~h}$ & 0.18 & 0.13 & 0.82 \\
\hline after $1000 \mathrm{~h}$ & 0.30 & 0.57 & 0.66 \\
\hline after $1500 \mathrm{~h}$ & 0.56 & 0.49 & 0.54 \\
\hline after $2000 \mathrm{~h}$ & 0.22 & 0.15 & 0.13 \\
\hline after $2500 \mathrm{~h}$ & 0.41 & 0.20 & 0.32 \\
\hline after $3000 \mathrm{~h}$ & 0.51 & 0.19 & 0.10 \\
\hline
\end{tabular}

As presented in fig. 6 quite big dispersion of results can be observed, but is should be mentioned that observed concentrations levels are below $1 \mathrm{mg} / \mathrm{L}$, which is a very low value. Some concentration changes can take place due to sample collection repeatability, and some other due to measurement reproducibility, and for that reason no significant conclusions can be drawn for these elements.

Another group of wear element is group including $\mathrm{Cu}$, $\mathrm{Al}, \mathrm{Ca}$ and $\mathrm{Zn}$. Concentrations of these elements were significantly higher than $1 \mathrm{mg} / \mathrm{L}$ and some trends in concentration levels changes can be observed (Fig. 7, Table 7). The highest concentration level during the whole test was observed for zinc $(\mathrm{Zn})$, and after initial increase in concentration of $\mathrm{Zn}$, some decrease was observed. Similar situation was observed for calcium $(\mathrm{Ca})$, which is an external con- 
tamination, but probably from connections in test stand. The concentration of copper $(\mathrm{Cu})$ was on similar level during the test, so it can be stated that no wear of components including $\mathrm{Cu}$ occurred.

The most important observation is that no significant increase of aluminum concentration was observed that clearly prove that no radiator wear took place.

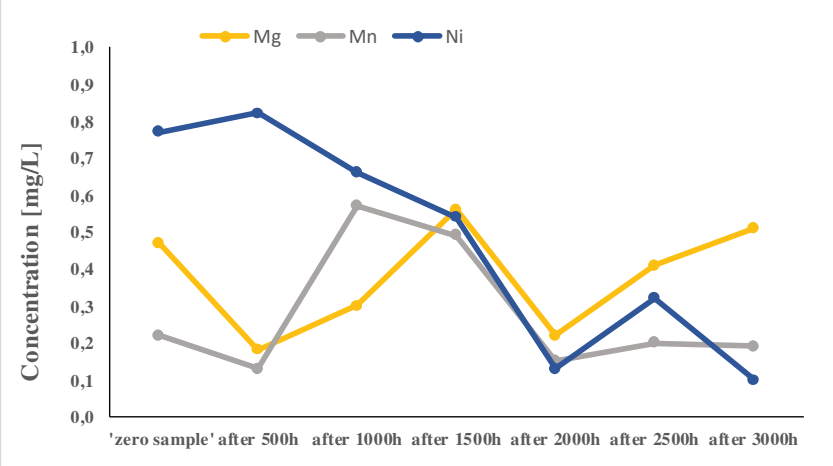

Fig. 6. Changes in $\mathrm{Mg}$, Mn and Ni concentration

Table 7. Changes in wear elements concentrations $[\mathrm{mg} / \mathrm{L}]$

\begin{tabular}{|c|c|c|c|c|}
\hline $\begin{array}{c}\text { Coolant } \\
\text { sample }\end{array}$ & $\mathrm{Al}$ & $\mathrm{Ca}$ & $\mathrm{Cu}$ & $\mathrm{Zn}$ \\
\hline 'zero sample' & 7.4 & 2.1 & 4.7 & 12.7 \\
\hline after $500 \mathrm{~h}$ & 5.8 & 2.1 & 2.6 & 16.2 \\
\hline after $1000 \mathrm{~h}$ & 4.4 & 3.6 & 5.1 & 19.5 \\
\hline after $1500 \mathrm{~h}$ & 12.5 & 6.1 & 3.8 & 19.5 \\
\hline after $2000 \mathrm{~h}$ & 6.8 & 2.2 & 3.5 & 22.0 \\
\hline after $2500 \mathrm{~h}$ & 12.1 & 7.3 & 1.1 & 19.1 \\
\hline after $3000 \mathrm{~h}$ & 9.0 & 5.2 & 1.6 & 16.6 \\
\hline
\end{tabular}

\section{Nomenclature}

MSDS Material Safety Data Sheet

ICP-OES inductively coupled plasma optical emission spectrommetry

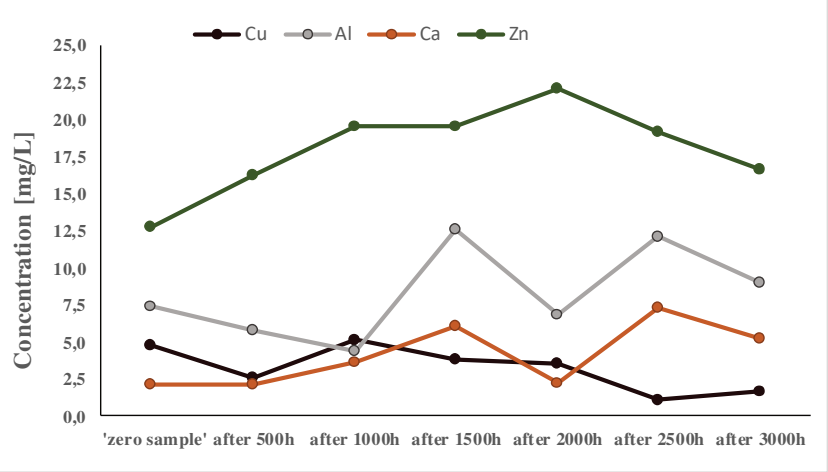

Fig. 7. Changes in $\mathrm{Cu}, \mathrm{Al}, \mathrm{Ca}$ and $\mathrm{Zn}$ concentration

\section{Conclusions}

During the $3003 \mathrm{~h}$ durability test of three radiators physical properties changes of cooling fluid were monitored: reserve alkalinity and $\mathrm{pH}$ value. It can be stated that coolant wear took place. Further performance of cooling fluid under study in prolonged durability test could be worsen due to further R.A. and $\mathrm{pH}$ value decrease. On the other hand no significant increase of wear elements concentrations were noticed, that can prove that no radiator wear occurred.

Periodical chemical analysis along with physical properties changes observations is a simple, but very helpful tool for radiator's material and cooling fluid wear monitoring.

\section{Acknowledgements}

The authors would like to acknowledge Maciej Szczugiet for the help in stand test performance.

R.A. Reserve Alkalinity

MDL Method Detection Limit

\section{Bibliography}

[1] ZOHURI, B. Heat exchanger types and classifications. Compact Heat Exchangers: Selection, Application, Design and Evaluation. Springer 2017. DOI: 10.1007/978-3-31929835-1.

[2] LALPURWALA, G.J., JANI, D.B. A critical review on heat transfer enhancement in a car radiator by use of nano fluid. IJRME - International Journal of Research in Mechanical Engineering. 2017, 04(04), 25-27. http://researchscript.com/ ijrme/ijrmevol4issue4/ijrme040406

[3] ADDEPALli, S., EIROSA, D., LIEOTRAKOOL, S. et al. Degradation study of heat exchangers. Procedia. CIRP 2015, 38, 137-142. DOI:10.1016/j.procir.2015.07.057.

[4] LIN, CH., SAUNDERS, J., WATKINS, S. The effect of changes in ambient and coolant radiator inlet temperatures and coolant flowrate on specific dissipation. SAE Technical Paper. 2000-01-0579. DOI:10.4271/2000-01-0579.

[5] PETA, K., GROCHALSKI, K. The measurements of temperature and deformations of car radiators. E3S Web of Conferences. 2017, 19, 1-4. DOI:10.1051/e3sconf/20171903033

[6] PETA, K., GROCHALSKI, K., PIASECKI, A., ŻUREK, J. The influence of sodium chlorides fog on corrosion re- sistance of heat exchangers used in automotive. Archives of Mechanical Technology and Materials. 2017, 37, 45-49. DOI:10.1515/amtm-2017-0007.

[7] OYA, Y., KOJIMA, Y., HARA, N. Influence of silicon on intergranular corrosion for aluminium alloys. Materials Transactions. 2013, 54(7), 1200-1208. DOI: 10.2320/matertrans.M2013048

[8] AHMED, A.S., OZKAYMAK, M., SÖZEN, A. et al. Improving car radiator performance by using $\mathrm{TiO}_{2}$-water nanofluid. Engineering Science and Technology, an International Journal 2018, 21, 996-1005. DOI: 10.1016/j.jestch. 2018.07.008.

[9] HARSH, R., SRIVASTAV, H., BALAKRISHMAN, P. et al. Study of heat transfer characteristics of nanofluids in an automotive radiator. IOPConference Series: Materials Science and Engineering. 2018, 310, 1-7. DOI; 10.1088/1757-899X/ 310/1/012117.

[10] VOON, F.C. Design and development of nanofluid car radiator test rig. Technical Report. 2015.

[11] SHEIKHZADEH, G., HAJILOU, M., JAFARIAN, H. Analysis of thermal performance of a car radiator employing 
nanofluid. International Journal of Mechanical Engineering and Applications. 2014, 2(4), 47-51. DOI: 10.11648/j.ijmea. 20140204.11.

[12] MUTUKU, W.N. Ethylene glycol (EG)-based nanofluids as a coolant for automotive radiator. Asia Pacific Journal on Computational Engineering. 2016, 3(1), 1-15. DOI: 10.1186/ s40540-016-0017-3

[13] SAXENA, G., SONI, P. Nano coolants for automotive applications: a review. Nano Trends: A Journal od Nanotechnology and Its Applications. 2018, 20(1), 9-22. techjournals.stmjournals.in/index.php/NTs/article/view/78.

[14] TL 774:2010, Ethylene Glycol-Based Coolant Additive, VW Standard 2010.
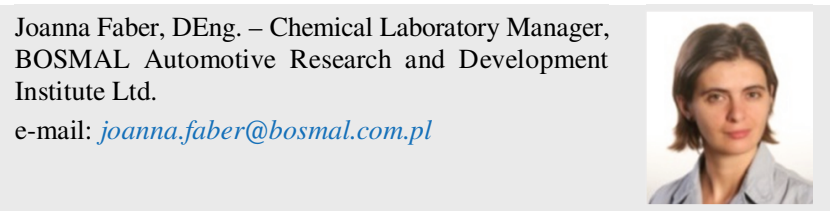

Krzysztof Brodzik, DEng. - Head of Materials Testing Department, BOSMAL Automotive Research and Development Institute Ltd.

e-mail: krzysztof.brodzik@bosmal.com.pl
[15] BASF: G48 ${ }^{\circledR}$ Data Sheet 2013.

[16] PN-C-40008-05:1993, Antifreeze fluids for heat exchangers for combustion engines. Determination of alkalinity reserve.

[17] PN-C-40008-04:1992, Antifreeze fluids for heat exchangers for combustion engines. Determination of $\mathrm{pH}$ value.

[18] PN-EN ISO 12185:2002, Crude petroleum and petroleum products. Determination of density. Oscillating U-tube method.

[19] www.borax.com/applications/industrial-fluids-lubricants.

[20] ANDERSON, D.P., MALTE, L., LYNCH, B.K. Diesel engine coolant analysis, new application for established instrumentation. Spectro Incorporated. 1998. https://archive.org/details/DTIC_ADA347981.

Zbigniew Jurasz, DEng. - Research and Technical Specialist in BOSMAL Automotive Research and Development Institute Ltd.

e-mail: zbigniew.jurasz@bosmal.com.pl
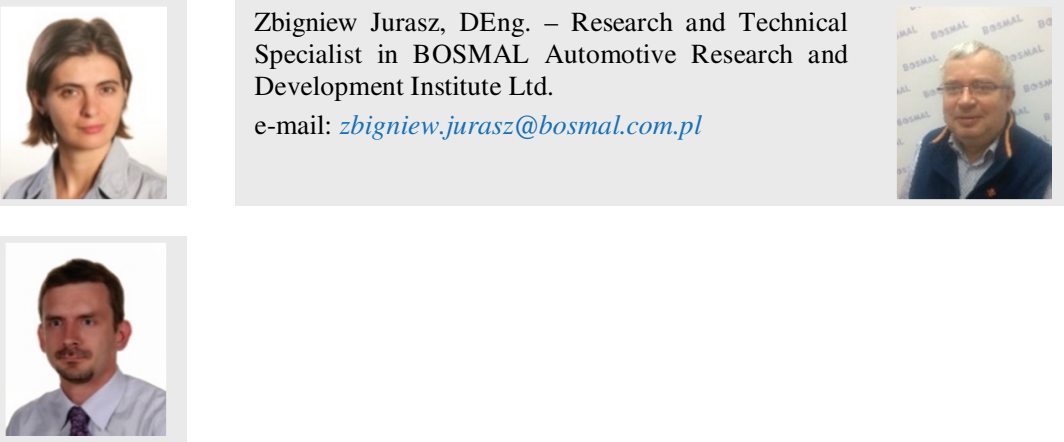